\title{
THE EMPOWERMENT OF CHILDREN IN EDITH NESBIT'S THE RAILWAY CHILDREN
}

\author{
Adam Anshori \\ Universitas Islam Indonesia \\ Email: adam.anshori@uii.ac.id
}

APA Citation: Anshori, A. (2016). The empowerment of children in Edith Nesbit's "The Railway Children". English Review, 4(2), 243-254

\begin{abstract}
This research is aimed at describing the empowerment of children in Edith Nesbit's The Railway Children. The problems formulated in the research will be answered in the descriptions consisting of thoughts, actions, and feelings of the main characters in the novel and presenting other characters' comments dedicated to the main characters. The main source of the research data was Edith Nesbit's The Railway Children. It is considered as a children's literature. The focus of the research was events in the novel which showing the empowerment of the main characters. The data consist of thoughts, actions, and feelings of the main characters and presenting other characters' admirable comments dedicated to the main characters. The data were analyzed inductively by using qualitative content analysis. The instrument of the research was the researcher himself. To get trustworthiness of the data, the researcher used four criteria, namely: credibility, transferability, dependability, and confirmability. The findings of the research showed that the novel contains of children's empowerment, which can be divided into three categories. They are Thought Empowerment, Action Empowerment and Feeling Empowerment. As empowerment of children is considered as an important aspect in children's story and it has great influence to enrich children's intelligence and emotion in their growing period, The Railway Children can be categorized as a good novel.

Keywords: children's literature, children's empowerment
\end{abstract}

\section{INTRODUCTION}

Childhood is seen as a crucial

formative period in life to gain basic education (Stephens, 1994:8). It is a time to learn about the nature of the world, how to live in it, how to relate to other people, how to face and solve problems, how to think, and what to believe. Children need something to teach them how to deal with life properly and honestly. For this reason, they need fair education. Fair education is education which is governed of excellence, and not orthodoxy, timidity, or intolerance, to encourage children's growing mind and critical thinking and to shape their future (West, 1998: viii-ix).
Unfortunately as one of the most influential subject in children's life, children's literature seems to have difficulties to be fair to children about the real facts in life. It is due to the fact that children's literature has a unique condition involving a conflict of interests between children and adults. Children, with their specific characteristics, interests, and knowledge, intentionally need to enrich themselves with lots of experiences from their readings. They want books that capable to challenge their critical thinking and empowering their growing mind. Children are also eager to have honest books about life, though it may be a bitter fact of life. On the other hand, most adults 
use and see children's literature from different point of view. They judge the value of a book, whether it is good or not, based on their own judgment. They feel that they have a right and better understanding to decide whether a book is suitable for children or not. Moreover, adults have authority and capability to do that. Many children consume children's reading and books which are brought and chosen by the adults.

Furthermore, adults treat children as ones who are innocent and need protection. Most authors of children's books do not explore the truth of life which is considered by adults dangerous and inappropriate, such as sexuality, poverty, and death, whereas children actually need fair stories about the real condition of life. Adults actually can tell children everything. However, adults must be aware of the way to present those things. The right way should be in children's range of understanding. Adults also use stories to inscribe their own judgments, wisdoms, beliefs, and norms. Those values will provide them with adults' approval of or hatred of something. Nodelman (1992: 1) said that children's literature is a form of adult style for dominating, restructuring, and having authority over childhood. So, it is obvious that children are victimized in their own reading materials because there are many stories which are not standing in their side.

Fairy tales, which are believed and assumed as children's literature, usually have values that may not consider children in particular (Tolkien, 1980: 113). Snow White and Seven Dwarfs, for example, contain value that a good kid is a child who never gazes and fights against her stepmother even though her stepmother is cruel. She took for granted to all things that her mother did to her even when her mother tried to kill her.
Fortunately, the soldier, who is ordered to kill her, saved her life. Then she hid in the jungle and depending her life to the kindness of the seven dwarfs. It shows that she is powerless and speechless. As a child, she depends and submits her whole life to adults, i.e., her stepmother, the soldier, and the seven dwarfs. This story will construct children's mind to be passive. Children are not stimulated to think critically and act bravely when they deal with adults. It also shows that adults dominate children. Children are filled with values for adults' benefit, so adults will be easier to handle children in their passive willingness.

This story does not empower Snow White, as the main character, who should have authority to decide her own life. This story also depicts that a girl is weaker than a boy. When a charming Prince suddenly appeared, he easily broke down the curse and saved her life. Then, as usual, the story ends happily ever after. It builds a frame of thought that children in their obedient and docile attitudes will get a happy life as her suffering repayment. So it will persuade children to believe that in their passive willingness, children will be blessed in their life. There is no argument or chance for them to fight against adults though actually the adults are wrong. Many fairy tales also inscribe unequal position between boy and girl. Girls are judged to be inferior to boys, whereas in fact it is untrue. They may do a lot of things as boys can. This value is dangerous because it can lead children's way of thinking into wrong belief or perception. Realizing this situation, adults should start to concern and be aware of their children's reading material. Children books may contain values that can endanger and harm them. It is seen in fairy tales as Snow White and Seven Dwarfs, which is considered as children's 
story. So, it is important for adults who have great authority and power toward children to pay more attention to this problem. Fair and wise adults must consider the need and desire of children who are longing for good books. Children want books that stimulate their critical thinking and growing mind and are able to answer their curiosity about life.

On the other hand, children deserve every ounce of their talent, intelligence, inventiveness, and care (Hunt, 1995: 18). Children need to learn about life from the right spectacles. They crucially need fair education and guidance. Children are only inexperienced. They are not innocent or speechless at all and actually they have their own wisdom to judge something. However, they need adults' guidance to figure out the hidden or profound values, and to stimulate them in developing an alert enjoyment in stories. Adults must be honest with them. Children may in their real life deal with situations that can be hard for them. Therefore, an opinion that children have to keep away from the bitter of life is unnecessary. Children experience the bitter of life from the everyday life instead of books. Hence, literature can be a mean to transfer knowledge and understanding to children to get a better preparation to deal with the real life.

A great value in children's literature is that it can help children recognize their feelings and be aware of things they do or not to do to cope with their feelings. Literature will also help children to be more apt to accept themselves if through stories they see other children with similar problems, worries, and conflicts (Jones, 1988: 27). A book must enlighten child's eyes and provide space for exploration, which extends their experiences, enjoyments, satisfaction and morality.

Considering the role of literature towards children, it seems necessary to conduct a research study concerning the influence of children's literature as a means of educating and exploring emotions and also as agent of socializations.

Character generally means the aggregate of mental, emotional, and social qualities that distinguish a person. In children's literature, the term character is used to mean a person, a personified animal or object that inhabits in a story (Lukens, 1999: 80). In the story, the importance of a character determines how fully the character is developed and understood by the readers. Character development means showing the character - whether a person or an animal or an object-with the complexity of human being (Lukens, 1999: 80).

A character may be presented mainly through description and discussion or, in a more dramatic manner; the author simply reports the character's speech and action. In other words, the readers may reveal the character through the action, speech, and appearance, others' comments and by author's comment. These methods of characterization can be used together (Little, 1981: 89). One extreme of dramatic method is the modern device of interior monologue or stream-ofconsciousness technique, in which all that is recorded is the flow of impression and thought passing through some character's mind from moment to moment.

Characters are divided into two, namely: dynamic and static character (Lukens, 1999: 86). Dynamic character is one who changes in the course of action. The character demonstrates a new realization about himself or herself, or 
about his or her personal values. Static character is one who does not change in the course of the story. The conflict does not influence the character to make any impact upon personality or outlook.

Children have keen interest in character (Lukens, 1999: 94). They want stories that its characters especially child characters involved in action and making decisions. Children are intent on the way characters' decisions solving the problems. Children like to follow characters and their motives through their emotions and their reasoning as they face decisions and make choices. They are also excited by the possibility of the accidental and also inevitable situations. These descriptions show the importance of characterization in children's literature in drawing meaning and messages and pleasing the children.

The Railway Children, as one of children's novels, is interesting to be studied from many perspectives, such as plot, characterization, point of view, and setting. In order to be focus on the research, the research will be restricted to the description of the main characters' thoughts, actions, and feelings and others' comments appraising them, showing their efforts to deal with their life and the empowerment characterization of the children. The limitation of the problems is mainly based on the relevance of the research question, which is "What kinds of children's empowerment appear in the novel?"

\section{METHOD}

This research uses qualitative method. Qualitative method is a research procedure which produces descriptive data results in the form of written or oral words from people and their behavior that are observed (Bogdan and Biken, 1982: 5). This method is concerned with the process rather than consequences, with organic wholeness rather than independent variables, and with meaning rather than behavioral statistics. It emphasizes a holistic interpretation.

The main source of the research is the novel entitled The Railway Children by Edith Nesbit who is best known for her family stories. The Penguin Group firstly publishes this novel in England in 1906 and through the time this novel was being revised and reprinted in 1995.

The data are analyzed by using content analysis. According to Holsti (in Lincoln and Guba, 1985: 337-338), content analysis is an objective, systematic, and general description of the manifest content of a text. This analysis has five major characteristics. Firstly, the process of analyzing the data follows certain formulated rules and procedures. However, it conforms that the rules do not need to be finally formulated until the end of the research. Secondly, it should be systematic. It deals with forming categories, which have to be done according to determined procedures. Thirdly, content analysis is a process that aims for generality by gaining theoretical relevance as the result of the analysis. Theoretical relevance produces relevant and theoretical perspectives in relation to the context. Fourthly, content analysis concerns manifested content. It will draw the conclusion based on the content of manifested context. Finally, although content analysis emphasizes more on quantitative research, it also can be carried out with qualitative research.

The qualitative content analysis procedure which is used in this research is inductive category development. Its procedure formulates a criterion of definition derived from theoretical background and research question which determine the aspect of the textual 
material taken into account (Mayring, 2000: 4).

The data of the research are events occurred in The Railway Children by Edit Nesbit that describe the empowerment of child characters to cope with their problems and feelings. The empowerment of children is shown through the capability and sensibility of children in solving their problems and others' problems and also understanding others' feelings. Beside the characterization of the child characters, children's empowerment is also strengthened by the praise of other characters for children's kindness. The focus of the research is events, which show the empowerment of the main characters, Roberta, Peter, and Phyllis to deal with their problems of lives and feelings.

According to Moleong the criteria to check the trustworthiness are credibility, transferability, dependability, and confirmability (Lincoln and Guba, 1985: 300). Credibility is aimed at achieving the validity of the data. The researcher can achieve credibility through carefully and comprehensively reading and re-reading the selected data in accordance with the research question so that the data can be considered credible. This criterion is done until the researcher gets certainty and could not find any other significant variation in the data.

The researcher also applies triangulation technique to gain credibility of the data. Triangulation utilizes something outside the data to verify the data itself or to compare them (Moleong, 2011: 178). Kinds of triangulation technique are sources, methods, observers or researchers, and theories. The researcher applies one technique of triangulation that is another observer. In this technique, the researcher asks another person to discuss the valuable data to know the correct interpretation about the events whether they are relevant to the children's empowerment or not. The person who became the observer is Widyastuti Purbani. She earns a doctorate degree from Universitas Indonesia majoring in Children's Literature. Therefore, her capability in analyzing children's literature will be in accordance with the research.

In applying transferability, the researcher should provide all the information needed by the readers in understanding the findings. This information that called thick description presents the detail and empirical findings, which describe the context of the research. The thick description is obtained through reading and analyzing The Railway Children comprehensively. To fulfill dependability, the researcher reads the data carefully and frequently in order to understand the content of the novel and to make correct interpretation. Triangulation technique is also used to reach this criterion. The researcher asks the observer as the second reader and has some discussions with her. In some discussions, the observer states that she has the same perspective as the researcher about the novel.

\section{RESULTS AND DISCUSSION}

There are many books written for children. Through this research, however, it will be impossible to analyze all of the books. The researcher only focuses on one book in order to have detailed analysis. The researcher chooses The Railway Children by Edith Nesbit because the main characters in the novel are children who get misfortune in their life. It shows the struggle of children in facing and solving their own problems.

According to Neufeldt (1996: 445) 'to give authority or power or ability to' 
is similar to the word "empower". Empowerment is the noun form of empower that is defined as giving authority, power, or ability to someone. In accordance with the situation of children's literature and the importance of good book for children, it is obvious that empowerment of children is crucial. Empowerment becomes a significant role in children's literature because children are eager to portray themselves in the story and tend to imitate what the characters do, especially the main character. When a story presents an empowerment spirit, it is expected that the readers are stimulated to think critically and do the same things as the empowering characters in order to draw the meaning of that story.

Nodelman sees the similarity frame of thought in Orientalism to the frame of thought used by adults over children. In Orientalism, Said reveals that Western (the Occidents) tends to dominate, restructure, and have authority over the East (the Orients) whereas in children's literature Nodelamn figures out the domination of adults (the authors) toward children (the readers). Nodelman borrows Said's Orientalism to make a brief description of the condition of children's literature. Nodelman (1992: 1) states:

“Children's psychology and children's literature can be discussed and analyzed as the corporate institution for dealing with childhood, dealing with it by making statements about it, authorizing views of it, describing it, by teaching it, settling it, ruling over it; in short, children's psychology and children's literature as an adult style for dominating, restructuring, and having authority over childhood"
The quotation above shows that adults (the authors) have power to control children (the readers) through the stories. An exploration of parallel insight between Said's description of Orientalism and the representation of childhood in children's literature reveals a number of characteristics not empowering children. Knowing the disempowerment characteristics in children's stories will help to figure out the empowerment values as the contrary side. Those characteristics are explained below.

\section{Inherent Inferiority} Inherent inferiority deals with adults' way of thought that posit themselves as superior, having more knowledge and ability, over children, the inferior one who are incapable to speak for themselves (Nodelman, 1992: 1). In children's literature, this characteristic is viewed from the author's way in treating their readers. They restrict themselves to create a complex story because of their lack of vocabulary and knowledge as a means to understand the story. Another form of inferiority is that the authors place child characters in a weaker side. This is obviously seen in fairy tales. Child characters in fairy tales, though they are the main characters in the story, are described powerless and speechless. They tend to depend on and entrust their life to adults.

\section{Inherent Femaleness}

This characteristic in children's literature manages to suggest something traditionally feminine about childhood and on the contrary something traditionally masculine about childhood (Nodelman, 1992: 2). This situation subordinates children to an inferior position. Adults, in this case, plant the seed of their wisdom to children. They 
gaze and talk about how charming or cute children are in passive willingness. Children's happiness is about pleasing them, bending their will, or doing what they want. Adults will give reward for obedient children and give punishment whenever children dare to disobey or gaze back.

\section{Inherent Adult-Centered} It mainly concerns the assumption that the authors of children's books write the stories to provide the children with values and images that adult approve of or feel comfortable with. By large, this effort is aimed to give values and behaviors that make children easier to handle: more passive, more docile, and more obedient. As a result, children will need adults' guidance and more willing to accept the need for it (Nodelman, 1992: 2).

\section{Silencing and Inherent Silence} Silencing and inherent silence deals with adults' effort to hide things, which are considered dangerous and inappropriate for children (Nodelman, 1992: 2). Adults want to protect children from the bitterness of life and taboo matter. For example they try to hide the matters of poverty, sexuality, and divorce, in order to believe that children are truly as innocent as they claim and that children's life are devoid from bitterness of life. They would rather have to lie than be forced to confront children as they really are or as they really speak, whereas children crucially need the truth. In fact, the over-protective behavior from adults and the writers of children's books precisely uneducated them.

\section{Thought Empowerment}

The Railway Children presents

Thought Empowerment that is thinking ability of the children through its child characters' knowledge or idea and understanding others feelings. The thinking ability here means the ability of children; Roberta (Bobbie), Peter (Pete), and Phyllis, to develop their critical thinking and growing mind in order to overcome the situations or problems, which happened around them. Thought Empowerment is divided into two parts. They are Thought Empowerment through Children's Knowledge or Idea and through Understanding Others Feelings.

1. Thought Empowerment through Children's Knowledge and Idea Children have their own intelligence in the form of their knowledge and idea. Knowledge includes their ability to understand something, familiarity gained by their experiences and information achieved, whereas, idea is about their plan, opinion, or conception of something.

The position of children, both in reality and story, is inferior. It is because adults assume children as innocent and docile. However, in The Railway Children, Bobbie, Peter and Phyllis are presented as an open mind and intelligent children. They quickly learn and understand new information that they achieved. The information, for children, will answer their curiosity and need of knowledge. It takes an important role in children's growth. Because of that, children crucially need fair and honest information of the description of life.

In this story, Bobbie, Peter and Phyllis accept new information about the equality position between boys and girls. When Peter ask Father whether girls can help to mend engine or not and Father explains that girls are able to do all the things that boys can. 
'Can girls help to mend engines?' Peter asked doubtfully. Father: 'Of course they can. Girls are just as clever as boys...(Nesbit, 1995: 5).

They learn this information first by comparing it with the fact in their daily life. In their reality, those three children mostly do their activities together. They never face any conditions that show imbalance ability between boys and girls. Children then understand that the girls Bobbie and Phyllis- actually can do all the things that boy - Peter - can do. This influences them to belief the truth of the information.

The belief of equality position will construct children's frame of thought. It empowers children to have self-confidence. Bobbie and Phyllis believe that they can do all things; on the other hand, Peter never doubts his sisters' capability. This will convince children that they can develop their ability and creativity to reach whatever they want in life without restricted by gender.

\section{Thought Empowerment through} Understanding Others' Feelings

Adults often assume that children are innocent, naïve, and weak. From that belief, adults think that it will be unnecessary to share or inform them about something considered difficult or complex. Adults, in daily life, usually try to hide the problems and bitterness of life, such as poverty and sadness in order to keep the children away from misery. However, children can feel and see what actually happened, and may understand the situation better than what adult's expected.

“Bobbie said,' Come on Phil; I'll race you to the gate.' And she started the race, though she hated doing it". (Nesbit, 1995: 111)
Mother does not realize that Bobbie knows her sadness. She thinks that Bobbie is only tired of walking slowly. Mother never expects that Bobbie can do something to lift her burden up by giving her a chance to be alone. Bobbie asks Phyllis to race to the gate so she has her own little time to release her misery without any attentions and disturbances from her kids. Bobbie's capability to think of a way to show her affection for Mother is a form of children empowerment.

\section{Action Empowerment}

The Action Empowerment mainly describes children's action, behavior, and attitude in dealing with incidents in their daily life. It is divided into two parts. They are Action Empowerment through Children's Bravery and through Doing Favor for Others.

\section{Action Empowerment through Children's Bravery \\ One of brave attitudes that} should be learned by everybody is the willingness to confess his or her mistakes. It is important to learn because this action may require nerve to do and to accept any following consequences. Peter can act and answer the Station Master's greeting as usual like nothing happened before. However, he realizes that if the Station Master greets him first, it is plausible that the Station Master has not recognized him by daylight. Peter does not want to feel uncertain about it. He takes a risk when he decides to inform the Station Master who he really is. He believes that it will be easier for both of them to make clear of this problem out.

'I thought perhaps you didn't know it was me that took the coals,' Peter went on,' when you said "Good 
ENGLISH REVIEW: Journal of English Education Vol. 4, Issue 2, June 2016
ISSN 2301-7554

https://journal.uniku.ac.id/index.php/ERJEE
Morning". But it was, and I'm sorry.

There.' (Nesbit, 1995: 38)

Peter wants the Station Master knows that he is the boy who has ever stolen the coals. Fortunately, the Station Master appreciates his bravery to confess his mistake. The Station Master already has forgiven him. He has recognized Peter before he greets Peter. Peter's nerve to confess should be regarded as a brave attitude. He can manage his own doubt and fear to decide a proper action in solving the problem out. His action indicates his responsibility and honest personality. After this occurrence, the Station Master becomes one of his new friends.

\section{Action Empowerment through Doing Favor for Others}

To live in a society, children have to learn how to make relationship with others. They face the fact that they have to deal and work with others in their daily life. It is important to establish mutual assistance in their surroundings. Bobbie, Peter and Phyllis are sociable kids. They make lots of new friends in their new neighborhood. They love to help other. There are many occasions that show their action in helping others. One of their actions is giving physical assistance to Mother. They try to lessen Mother's duty by doing their own daily activities.

'... No servant or anything. Let's get up and to be useful. We'll just creep down mouse quietly and have everything beautiful before mother gets up.' (Nesbit, 1995: 20)

In this story, the children have selfawareness to be accustomed to their duty of daily activities. It is a good habit to train discipline and responsibility. If they are able to do their daily duty well, they may be ready to a greater responsibility.

\section{Feelings Empowerment}

Feeling Empowerment is a form of children's awareness and sensibility to deal with happening incidents. It is divided into two parts. They are Feeling Empowerment through Empathy and through Children's Unselfishness.

\section{Feeling Empowerment through Empathy \\ Empathy is an ability to share} another's emotion, thoughts or feelings. It is closely related to understand other's feeling. Children usually face difficulties to understand other's feeling because of their less experience. To have sensitivity and awareness of the surroundings, children need practice. They have to learn about expressions, signs, or attitudes of a person to consider his real feelings. Bobbie shows her deep empathy to the Russian stranger for his suffering. She knows that he almost gives up finding his wife and kids. So when the doctor unconsciously laughs at Bobbie's story about the crying Russian, she directly admonishes the doctor.

'Please don't. You wouldn't if you'd seen him before. I never saw a man cry before. You don't know what it's like." (Nesbit, 1995: 73)

Bobbie knows that it is hard for a man crying for his life. So, when the Russian stranger cries in front of the crowd, she can feel that he is in a very distress and hopeless condition. The fact that he arrives in a foreign country without any money and ability to communicate with others makes him totally lost. Moreover, he could not find any clues about his family existence in that country. It makes Bobbie understands why he cries. The doctor realizes his mistake and feels sorry for what he has done. It illustrates that sometimes children have better sensitivity than adults. 
2. Feeling Empowerment through Children's Unselfishness

Unselfishness is the way of thinking or attitude of someone who tries to consider other's need or welfare. It is a care expression for others. Children express their unselfishness attitude on many occasions in the story. When Peter gets involve in trouble, his sisters do not leave him alone to face it. They do things to help him, such as defending him or asking forgiveness for him.

'It's our fault just as much as Peter's. We helped to carry the coal away and we knew where he got it." (Nesbit, 1995: 32)

It is clear that Bobbie tries to exempt him. She tries to persuade the Station Master to forgive Peter's mistake. If the Station Master punishes him, Bobbie and Phyllis will deserve to get it too. The Station Master considers that Peter actually has no intention of doing a crime. He only has a wrong perception of coal mining. His sisters try to convince the Station Master, and they succeed. He lets them go. Their effort to help Peter when he is in trouble shows their kindness and tolerance. Tolerance is one form of unselfishness behavior.

Empowerment becomes the most interesting discussion in The Railway Children. This value is considered to have great influence in the improvement of children's intelligence and emotion. Child characters in children's story are the best picture and reflection of life for them. They can portray themselves in the story, which will stimulate them to expand their experience.

\section{CONCLUSION}

There are three kinds of empowerment in children characters, namely: Thought Empowerment, Action Empowerment, and Feelings
Empowerment. Thought Empowerment focuses on thinking ability of the children coping with the situations or problems which happen around them. It consists of two parts. They are empowerment seen through children's knowledge or idea and their understanding of other's feelings. Action Empowerment describes children's action, behavior, and attitude to overcome incidents in their everyday life. This type of empowerment is divided into two. They are empowerment seen through children's bravery and their action to give favor for others. Feeling Empowerment shows children's awareness and sensibility to understand other's feeling. Their awareness and sensitivity mainly deals with terrible feeling of others. Feeling Empowerment also consists of two parts. They are empowerment seen through children's empathy and their unselfishness.

\section{ACKNOWLEDGEMENT}

In this section, the researcher personally wants to thank Widyastuti Purbani as the second observer. She plays an important role in order to make the data of this research credible. The researcher also wants to thank Afdina Afitri as partner for discussion. As fellow researcher which have the same interest in children's literature, the discussion which we conduct help to determine the objectiveness of the research.

\section{REFERENCES}

Bogdan, R. C., \& Bilken, S.K. (1982). Qualitative Research for Education: An Introduction to Theory and Methods. Boston: Allyn and Bacon, Inc. (5)

Hunt, P. (1995). Criticism, Theory, and Children's Literature. Massachussets: Blackwell Publishers Inc. (18) 
ENGLISH REVIEW: Journal of English Education Vol. 4, Issue 2, June 2016

Jones, C. (1998). Parents are Teacher too. Vermont: Williamson Publishing Co. (27)

Lincoln, Y. S., \& Guba, E. G. (1985). Naturalistic Inquiry. Baverly Hills: Sage Publication, Inc. (300)

Little, G. (1981). Approach to Literature. New South Wales: Sciences Press. (89)

Lukens, R. J. (1990). Genre in Children's Literature in Critical Handbook in Children's Literature ( $4^{\text {th }}$ ed). New York: Harper Collins. $(80,86)$

----- (1999). A Critical Handbook of Children's Literature. New York: Addison-Wesley Educational Publishers, Inc. (94)

Mayring, P. (2000). Qualitative Content Analysis. Volume 1, No. 2 \&\#8211 (4)

Moleong, L. J. (2001). Metodologi Penelitian Kualitatif. Bandung: PT. Remaja Rosdakarya. (178)

Neufeldt. (1996). Webster's New World College Dictionary (3rd Ed.). New York: Simon and Schuster, Inc. (445)
ISSN 2301-7554

https://journal.uniku.ac.id/index.php/ERJEE

Nesbit, E. (1995). The Railway Children. New York: Penguin Books. (5, 20, 32, 38, 73, 111)

Nodelman, P. (1990). The Hidden Meaning and The Inner Tale: deconstruction and the Interpretation of Fairy Tales in Children's Literature Association Quarterly. Volume 15 No 3. (1-2) (1992). The Other: Orientalism, Colonialism, and Children's Literature. Spring Vol 17 No 1. (1)

Stephens, J. (1994). Language and Ideology in Children's Fiction. New York: Longman Publishing. (8)

Tolkien, J. R. R. (1980). Children and Fairy Stories. In only Connect-Readings on Children's Literature ( $\left.2^{\text {nd }} E d\right)$. Toronto: Oxford University Press. (113)

West, M. I. (1988). Trust Your Children: Voices Against Censorship in Children's Literature. New York: Neal-Schumann Publisher Inc. (viii-ix) 
